Open Houses 
This page intentionally left blank 


\section{Open Houses}

Poverty, the Novel, and the Architectural Idea in Nineteenth-Century Britain

Barbara Leckie

\section{PENN}

UNIVERSITY OF PENNSYLVANIA PRESS

PHILADELPHIA 
A volume in the Haney Foundation Series, established in 196I with the generous support of Dr. John Louis Haney.

Copyright (C) 2018 University of Pennsylvania Press

All rights reserved. Except for brief quotations used for purposes of review or scholarly citation, none of this book may be reproduced in any form by any means without written permission from the publisher.

Published by

University of Pennsylvania Press

Philadelphia, Pennsylvania I9IO4-4II2

www.upenn.edu/pennpress

Printed in the United States of America on acid-free paper IO $98 \begin{array}{lllllll} & 8 & 6 & 4 & 3 & 2 & \text { I }\end{array}$

Library of Congress Cataloging-in-Publication Data

Open houses: poverty, the novel, and the architectural idea in nineteenth-century Britain / Barbara Leckie.

Other titles: Haney Foundation series.

Description: Ist edition. | Philadelphia: University of Pennsylvania Press, [2018] | Series: Haney Foundation series | Includes bibliographical references and index.

Identifiers: LCCN 2017058049 | ISBN 97808I2250299 (hardcover: alk. paper)

Subjects: LCSH: English literature—-19th century-History and criticism. | Working class-Dwellings_-Great Britain-History—-I9th century. |

Architecture, Domestic_Great Britain-History_-Igth century. |

Housing-Great Britain-History—-Igth century. | Architecture,

Domestic, in literature. | Dwellings in literature. | Poor in literature. |

Architecture and society-Great Britain-History—igth century. |

Literature and society-England-History-igth century.

Classification: LCC PR468.H63 L43 20I8 | DDC 823/.8093556-dc23

LC record available at https://lccn.loc.gov/20I7058049 
For Joel, Michal, and Ben 
This page intentionally left blank 